\title{
Chemical Profiles and Anti-termite Activity of Hydrodistillation Residues From Three Aromatic Plants Acclimated in Burkina Faso
}

\author{
Assétou Sankara ${ }^{1}$, Jean Claude W. Ouédraogo ${ }^{1}$, Luc Pignolet ${ }^{2,3}$, Marie-France Thévenon ${ }^{2,3}$ \\ \& Yvonne L. Bonzi-Coulibaly ${ }^{1}$ \\ ${ }^{1}$ Laboratoire de Chimie Analytique, Environnementale et Bio-organique, Université Joseph KI-ZERBO, \\ Ouagadougou, Burkina Faso \\ ${ }^{2}$ UR BioWooEB, CIRAD, Montpellier, France \\ ${ }^{3}$ BioWooEB, Université de Montpellier, CIRAD, Montpellier, France \\ Correspondence: Yvonne L. Bonzi-Coulibaly, Laboratoire de Chimie Analytique, Environnementale et \\ Bio-Organique, Université Joseph KI-ZERBO, 03 BP 7021 Ouagadougou 03, Burkina Faso. Tel: 226-7023-9687. \\ E-mail: yvonne.bonzi@yahoo.fr
}

Received: May 28, 2020

doi:10.5539/jas.v12n8p245
Accepted: July 1, $2020 \quad$ Online Published: July 15, 2020

URL: https://doi.org/10.5539/jas.v12n8p245

\begin{abstract}
Distillation process of aromatic plants produces a considerable amount of solid residues, which are rich in secondary metabolites known as bioactive compounds. In this context, residues from hydrodistillation of selected aromatic plants such as Mentha piperita L., Cymbopogon citratus Stapf and Eucalyptus camaldulensis Dehnh, have been studied for their total polyphenol content using Folin-Ciocalteu Reagent (FCR) method, total flavonoid content using aluminium chlorid $\left(\mathrm{AlCl}_{3}\right)$ and antioxidant properties were determined as DPPH radical-scavenging ability $\left(\mathrm{IC}_{50}\right)$. The anti-termite activity was evaluated by a direct non-choice test. The higher antioxidant activity $\left(\mathrm{IC}_{50}=0.20 \mathrm{mg} / \mathrm{ml}\right)$ and polyphenols content $(224.32 \mathrm{mg} \mathrm{GAE} / \mathrm{g}$ of dried extract $)$ were showed with E. camaldulensis aqueous extract. However, M. piperita and C. citratus ethanolic extracts showed higher flavonoid content (190.99 and $185.19 \mathrm{mg}$ QE/g of dried extract). The most active extract against termite Reticulitermes flavipes was E. camaldulensis ethanolic extract presenting toxicity at $5 \%$ and $10 \% \mathrm{w} / \mathrm{w}$ as concentrations. All these data showed that strategic extraction of residues from hydrodistillation can provide interesting bioactive compounds as novel anti-termite agents in plants protection and allow to give an added-value to aromatic plants.
\end{abstract}

Keywords: antioxidant, bioactive compounds, flavonoids, non-choice test, plant extracts, polyphenols, Reticulitermes flavipes

\section{Introduction}

Aromatic plants are generally exploited for their essential oils, known for various biological activities throughout history. These well documented volatile substances can be extracted from different parts of plants such as root, wood, bark, foliage, flower, fruit, bud and stem (Irshad et al., 2019). Volatile terpenoids are major constituents of these essential oils largely studied and used for their biological activities. In addition, other secondary metabolites such as saponins, tannins, flavonoids and alkaloids present in plants are also of interest (Miean \& Mohamed, 2001; Texeira et al., 2013). If the yield of essential oil from an aromatic plant can range from 0.05 to $18 \%$, it generally stays below $5 \%$ and consequently a large amount of residues generated during the extraction processing remain a source of various natural bioactive products (Sankarikutty \& Narayanan, 2003). These bioactive compounds have demonstrated their potentialities for health benefits and pest management (Santana-Méridas et al., 2012, Olufunmilayo et al., 2012). Therefore, to face the limited bioresources, and in the scope of a sustainable green chemistry, using these wastes to isolate and characterize active molecules is of major interest (García-Serna et al., 2007; Hannon \& Zaman, 2018; Santana-Meridas et al, 2014; Mirabella et al., 2014). In this context, several studies have showed that residues from distillation process are rich in phenolics which can be exploited as health-promoting compounds, antioxidants in food and feed or anti-aging ingredients in cosmetic products (Navarrete et al., 2011; Torras-Claveria et al., 2007; Moure et al, 2001). 
Amidst the plant species widely available in Burkina Faso, Cymbopogon citratus (Stapf, 1906) (Poales: Poaceae), Eucalyptus camaldulensis (Dehnh., 1832) (Myrtales: Myrtaceae) and Mentha piperita (Linné, 1753) (Lamiales: Laminaceae) respectively called commonly lemongrass, mentha or mint and eucalyptus are of interest as they are known for their biological activities and are used in folk medecines (Lawal et al., 2017; Mahendran \& Rahman, 2020; Zerbo et al., 2011; Morin et al., 2017). The compounds extracted from C. citratus (Negrelle \& Gomes, 2007) exhibited antibacterial, insecticidal and antifungal activities. Ilboudo et al. (2016) have established that flavonoid extracts obtained from M. piperita leaves reduced in vitro the mycelium growth of Phoma sorghina (Sacc.) (Boerema, Dorenbosch, \& van Kesteren, 1973) (Pleosporales: Pleosporaceae) and Fusarium moniliforme (Link, 1809) (Hypocreales: Nectriaceae) by $72 \%$ and $55 \%$, respectively, when used at a concentration of 5 $\mathrm{mg} / \mathrm{ml}$. Many studies have highlighted E. camaldulensis biological properties and its application against many diseases (Abu-Jafar \& Huleihel, 2017; Ghasemian et al., 2019). Its leaf extracts were studied and showed to contain tannins, saponins, triterpenoids (Adeniyi \& Ayepola, 2008; Siddiqui et al., 2000), many potential antioxidant compounds as chlorogenic acid, phloroglucinol derivatives, galloyl-HHDP glucopyranose or ellagitannin dimers (Singab et al., 2011). The n-Butanol extract of these leaves controlled efficiently black spot pathogen of Pisum sativum (Linné, 1753) (Fabales: Fabaceae) with 78\% growth suppression (Shafique \& Ahmed, 2017). According to Espana et al. (2017), E. camaldulensis ethanolic extract provided $98 \%$ of Colletotrichum gloeosporioides (Penz \& Sacc., 1884) (Incertae sedis: Glomerellaceae) growth inhibition at $5000 \mathrm{mg} / \mathrm{L}$. As human medicine, Abu-Jafar \& Huleihel (2017) reported the potential antiviral activity against some herpes virus by ethanolic extract of $E$. camaldulensis leaves. The extract of $E$. camaldulensis was also evaluated for its anticorrosive potentiality (Ghareeb et al., 2018). The important biological properties of no-volatile active compounds from aromatic plant residues could be used as bio-pesticides for integrated pest management.

Amongst the insects present in West Africa, and therefore in Burkina Faso, termites are of major interest (Kaiser et al., 2015). They play an essential role in ecosystems due to their diversity, and, their service in organic matters decomposition, hydrology, as well as soil fertility (Jouquet et al., 2011; Kaiser et al., 2015; Korb et al., 2019). However, some termite species are major pests which attack various crops, household materials, wood and plants (Schyra \& Korb, 2019) and can cause major economic losses (Ibrahim \& Adebote, 2012). To avoid chemical pesticide use in crops production and forests plantation, investigation was done with natural products to control termite infestation. In the course of search for cheap naturally-occurring products for termiticidal activity by valorization of residues after hydrodistillation of aromatic plants, we aimed to investigate phenolics as they present potential pesticidal activities. In this work, we have tentatively quantified the phenolic compounds present in the residues after the hydrodistillation of M. piperita, C. citratus and E. camaldulensis and evaluated their antioxidant property and anti-termite activity towards Reticulitermes flavipes (Kollar, 1837) (Blattodea: Rhinotermitidae) under laboratory conditions.

\section{Materials and Methods}

\subsection{Chemicals and Reagents}

All the chemicals, reagents and solvents used were analytical grade: butanol, acetic acid, distillated water and ethanol for extraction (as bioethanol 70\%).

Formic acid, gallic acid as well as the thin layer chromatography (TLC) plates (60 F254 silica gel plate on aluminum support) were purchased from Merck (Darmstadt, Germany).

Methanol (HPLC-MS grade), both flavonoid standards (quercetin and gallic acid), diphenyl-1-picrylhydrazyl (DPPH), Neu (diphenylboryloxyethylamine), Aluminium chlorid $\mathrm{AlCl}_{3} 2 \%$, Sodium carbonate, Trolox from and sodium carbonate were provided by Sigma-Aldrich (Steinheim, Germany). Folin-Ciocalteu Reagent was purchased from Fluka Analytical.

\subsection{Plant Material Collection and Treatment}

The aerial parts (fresh leaves) of each plant (1) M. piperita, (2) C. citratus, (3) E. camaldulensis were collected at Ouagadougou (Burkina Faso), March 2018. The plant material was washed with distilled water, air dried at room temperature (r.t.) for seven days and then powdered.

\subsection{Extraction Procedures for Aqueous and Ethanolic Extracts}

Sample (100 g) of air dried plant powder was hydrodistilled using a Clevenger type apparatus. The remaining crude mixture was filtered to obtain an aqueous solution and a solid residue. The aqueous solution was submitted to lyophilization with a LABCONCO FreeZone 2.5 Plus apparatus to obtain the aqueous extract. The solid residue obtained was dried for $72 \mathrm{~h}$ at r.t., and then, macerated under continuous magnetic stirring with $1 \mathrm{~L}$ of 
ethanol (70\%) for $24 \mathrm{~h}$ at r.t. The solvent was evaporated using rotavapor R-100 at $40{ }^{\circ} \mathrm{C}$ under $175 \mathrm{mbar}$ to obtain the ethanolic extract.

From the three plants, six extracts were obtained and named; Cymbopogon citratus Aqueous and Ethanolic extracts: CA and CE respectively; Eucalyptus camaldulensis Aqueous and Ethanolic extracts: EA and EE respectively; Mentha piperita Aqueous and Ethanolic extracts: MA and ME respectively.

The extraction yield for the six extracts was expressed in $\% \mathrm{w} / \mathrm{w}$ as ratio between the obtained mass after extraction and the mass of air dried plant powder used $(100 \mathrm{~g})$.

\subsection{Ash Determination}

Ash determination was performed by combustion of the biomass. A sample $(2 \mathrm{~g})$ of the air dried powder or the extract was weighed in a crucible and placed in a furnace at $550{ }^{\circ} \mathrm{C}$ during $3 \mathrm{~h}$. The crucible was cooled in a dessicator and weighted. The ash percentage was calculated using the following formula:

$$
\text { Percentage of ash }(\%)=\frac{\text { weight of ash }}{\text { weight of sample }} \times 100
$$

\subsection{Qualitative Identification of Flavonoids by TLC Development}

Flavonoids were investigated in the six extracts by thin layer chromatography (TLC) with the reagent of Neu as developer. Each extract was dissolved at $20 \mathrm{mg} / \mathrm{ml}$ in methanol. A volume of $5 \mu \mathrm{l}$ of each solution was charged as spot on the plate. After the application of the spots, the chromatogram was developed in a glass chamber $(20 \times 20$ $\mathrm{cm}$ ) satured during 25 minutes with the elution's solvent and in the presence of a No. 1 Whatman filter paper. The eluent system used was Butanol-Acetic Acid-Water (65/15/20-v/v/v). After elution, the plate was air-dried, heated for $5 \mathrm{~min}$ at $105^{\circ} \mathrm{C}$ and observed at the wavelengths $254 \mathrm{~nm}$ and $365 \mathrm{~nm}$ under a UV lamp. Once sprayed with Neu reagent $(1 \% \mathrm{w} / \mathrm{v}$ in $\mathrm{MeOH})$, the detection of flavonoids was observed at $365 \mathrm{~nm}$.

\subsection{Total Phenolic Content Measurement}

The content of total polyphenols (TP) of extracts was determined by the Folin-Ciocalteu colorimetric method (Singleton et al., 1999). To $1 \mathrm{~mL}$ of each extract solution was added $1 \mathrm{~mL}$ of Folin-Ciocalteu reagent $(2 \mathrm{~mL}$ diluted 10 times in distilled water) and after 8 minutes, $2 \mathrm{~mL}$ of sodium carbonate $\left(1.6 \mathrm{~mL}\right.$ of $7.5 \% \mathrm{Na}_{2} \mathrm{CO}_{3}$ prepared in distilled water) were added. After $1 \mathrm{~h}$ of incubation in the dark at r.t., the absorbance was measured at $765 \mathrm{~nm}$ using BMG Labtech SPECTROstar Nano spectrophotometer against a blank. The standard calibration curve $(0.00048-0.03125 \mathrm{mg} / \mathrm{mL})$ was prepared from gallic acid, and the total phenolic content was calculated as the average of triplicate data for each sample in milligram equivalents of gallic acid per gram dry extract (mg $\mathrm{GAE} / \mathrm{g})$. Linear regression analysis equation $\left(\mathrm{y}=0.015 \mathrm{x}+0.026, \mathrm{R}^{2}=0.9994\right)$, was applied to calculate TP in which $\mathrm{y}$ is absorbance at $415 \mathrm{~nm}$ and $\mathrm{x}$ is the amount of gallic acid equivalent (GAE) in mg per gram extract.

\subsection{Total Flavonoid Content Measurement}

The total flavonoid (TF) content was determined using the method $\mathrm{AlCl}_{3}$ (Woisky \& Salatino, 1998) with modifications. Two (02) $\mathrm{mL}$ of aluminium chloride $\mathrm{AlCl}_{3} 2 \%$ methanolic solution were added to $2 \mathrm{~mL}$ of plant extract solution. Extracts were evaluated at a final concentration of $0.25 \mathrm{mg} / \mathrm{mL}$. After $40 \mathrm{~min}$ incubation at r.t, the presence of a yellow color indicates the presence of flavonoids. The absorbance at $420 \mathrm{~nm}$ was then measured using BMG Labtech SPECTROstar Nano spectrophotometer against a blank. The amount of flavonoids in the extract is calculated was expressed as milligram equivalent of quercetin per gram of dry extract $(\mathrm{mg} \mathrm{QE} / \mathrm{g})$, using a calibration range with quercetin as a standard.

\subsection{Determination of Antioxidant Activity by DPPH Method}

The 2.2-diphenyl-1-picrylhydrazyl (DPPH) inhibition assay was performed using the modified Brand-Williams method by Miliauskas et al. (2004). The solution of the DPPH radical $\left(6 \times 10^{-5} \mathrm{M}\right)$ was prepared by dissolving $2.36 \mathrm{mg}$ DPPH in $100 \mathrm{~mL}$ of methanol. At $150 \mu \mathrm{L}$ of methanolic solution of each extract were added $4.5 \mathrm{~mL}$ of DPPH solution. The solutions were incubated at $28^{\circ} \mathrm{C}$ in a water bath for $20 \mathrm{~min}$ before reading the absorbance at $515 \mathrm{~nm}$. The absorbance was measured using BMG Labtech SPECTROstar Nano spectrophotometer against a blank. The percentage of DPPH inhibition was calculated as the average of triplicate data for each concentration of sample according to the following formula:

$$
\% \text { inhibition }=\frac{A_{B}-A_{E}}{A_{B}} \times 100
$$

where, $\mathrm{A}_{\mathrm{B}}$ : blank absorbance and $\mathrm{A}_{\mathrm{E}}$ : sample absorbance.

The percentage of inhibition was plotted against sample concentration and using linear regression the $\mathrm{IC}_{50}$-value in $\mathrm{mg} / \mathrm{mL}$ was calculated. All samples were prepared and analyzed in triplicate. Absorbance of Trolox, taken as a 
reference, was measured and was $\mathrm{IC}_{50}: 0.15 \mathrm{mg} / \mathrm{ml}$. The rate of inhibition of the radical was calculated to the same formula.

\subsection{Anti-termite Activity Evaluation}

Reticulitermes flavipes were collected in Saint Trojan les Bains forest, Oleron Island, France. Once collected, the termites were kept in breeding boxes, in dark climatic chambers at $27{ }^{\circ} \mathrm{C}$, Relative Humidity (RH) above $80 \%$, and fed with poplar (Populus spp.) timber.

Anti-termite activity was conducted using a non-choice test against $R$. flavipes using a $1 \mathrm{~cm}^{2}$ Joseph filter paper, made of pure cellulose (grammage $25 \mathrm{~g} / \mathrm{m}^{2}$, Filtatrech). Aqueous and ethanolic extractives were diluted in ethanol $\mathrm{w} / \mathrm{w}$ at concentrations $2.5 \%, 5 \%$ and $10 \%$. A volume $(30 \mu \mathrm{L})$ of each diluted solutions was impregnated on the filter paper samples using a micropipette. Filter papers were also treated with the same amount of ethanol or water, as solvent and virulence controls respectively. Each treatment was done in triplicate. The treated papers were left to dry at room conditionned $\left(20^{\circ} \mathrm{C}\right)$ for $15 \mathrm{~min}$. Petri dishes $(9 \mathrm{~cm}$ in diameter) were filled with $30 \mathrm{~g}$ of wet Fontainebleau sand ( 1 vol. water $/ 4$ vol. of sand). The wet sand is distributed at the periphery of the Petri dish, leaving its center free of sand, where the treated paper was fitted. The treated paper was placed of a plastic mesh to avoid waterlogging during the test. Twenty termite workers were introduced in each Petri dish, the test being done in triplicates (Figure 1). The test devices were placed in a dark room at $27{ }^{\circ} \mathrm{C}$, with a RH above $75 \%$, observed regularly, the sand being re-humidified at regular intervals. The test was carried until total degradation of the filter paper or up to 24 days. In the case of water and ethanol controls, the filter paper was replaced when totally degraded, in order to keep feeding the termites along the test. At the end of the test, the surviving termites were counted and the survival rate was calculated according to:

$$
\% \mathrm{SR}=\frac{\mathrm{NST}}{20} \times 100
$$

where, $\%$ SR: Survival rate $\%$ and NST: Number of surviving termites.

The surface degradation (SD) expressed in \% of the paper was evaluated (using a tracing graph paper) and expressed as:

$$
\% \mathrm{SD}=\frac{\mathrm{SFP}}{\mathrm{ISF}} \times 100
$$

where, \%SD: Surface Degradation percentage, SFP: Surface of the filter paper at the end of test $\left(\mathrm{mm}^{2}\right)$ and ISF: Initial Surface of the filter paper $\left(\mathrm{mm}^{2}\right)$.

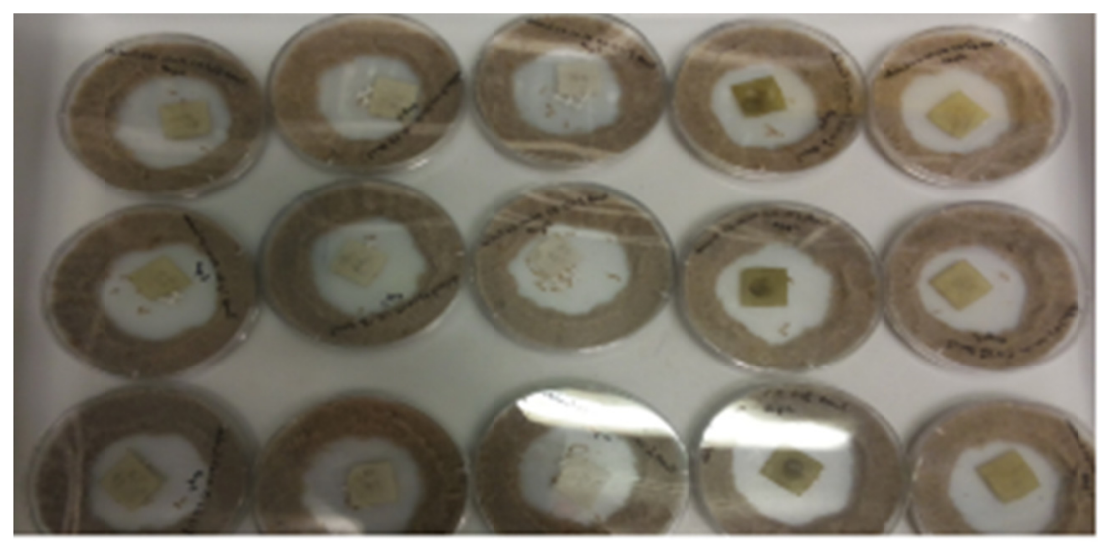

Figure 1. Non-choice termite tests

\subsection{Statistical Analysis}

Analysis of data was carried out by ANOVA one way. Comparison of mean values was performed with the Student-Newman-Keuls range test at the $(\mathrm{P}=5 \%)$ level using the SPSS 22.0 program.

\section{Results}

\subsection{Extraction Yields and Ash Contents}

The results on the extraction yield are given for the six extracts (Table 1). 
Table 1. Extraction yields data $(\% \mathrm{w} / \mathrm{w})$

\begin{tabular}{llll}
\hline Plant & C. citratus & E. camaldulensis & M. piperita \\
\hline Aqueous extract & 17.80 & 28.60 & 26.85 \\
Ethanolic extract & 04.63 & 13.64 & 04.45 \\
Total & $\mathbf{2 2 . 4 3}$ & $\mathbf{4 2 . 2 4}$ & $\mathbf{3 1 . 3 0}$ \\
\hline
\end{tabular}

Values of extraction yields varying from $4.45 \%$ to $28.6 \%$ are observed for the three plants. Ethanolic extracts of $C$. citratus and M. piperita present the lower yields around $4 \%$, while $E$. camaldulensis presents aqueous extraction yield found at $28.6 \%$.

The ash contents are evaluated for crude powder and aqueous water and represented on a histogram (Figure 2).

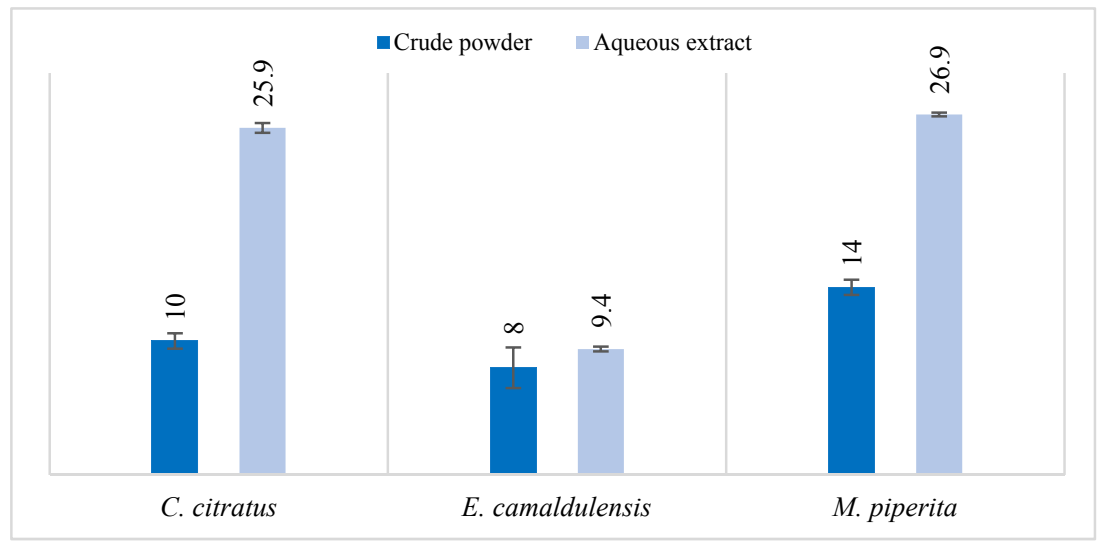

Figure 2. Histogram of ash contents $(\% \mathrm{w} / \mathrm{w})$

Aqueous extracts contained minerals in contrast to ethanolic extracts which present no residual ash for the three plants. Regarding the ash percentage, E. camaldulensis has the lowest value (8\%) for the crude leave's powder and M. piperita the highest value $(29.6 \%)$. Aqueous extract of $C$. citratus gave $25 \%$ as ash part corresponding to the $17.8 \%$ of extract. This means that aqueous extract of $C$. citratus can be partitioned about $4.4 \%$ of minerals and $13.4 \%$ of organic extractives for the all powder.

Eucalyptus camaldulensis presents a low level of minerals (8\%) in the crude powder, and in its aqueous extract, the percentage of minerals increases lightly up to $9 \%$ because of the high extraction yields with water. As opposite to, water extraction of $M$. piperita and C. citratus increased the ash content by far.

\subsection{Total Polyphenol (TP) and Total Flavonoid (TF) Contents}

For polyphenols and flavonoid contents (Table 2), the TP of the six extracts present variation ranged from $224.31 \pm 16.69$ to $47.12 \pm 3.69 \mathrm{mg} \mathrm{GAE} / \mathrm{g}$.

Table 2. Contents in phenolics, flavonoids and antioxidant activity of plant extracts

\begin{tabular}{llll}
\hline Extracts & $\begin{array}{l}\text { Contents in polyphenols TP } \\
(\mathrm{mg} \mathrm{GAE} / \mathrm{g} \text { dry extract) }\end{array}$ & $\begin{array}{l}\text { Contents in flavonoids TF } \\
(\mathrm{mg} \mathrm{QE} / \mathrm{g} \text { dry extract) }\end{array}$ & DPPH IC $_{50}(\mathrm{mg} / \mathrm{ml})$ \\
\hline $\mathrm{CA}$ & $66.2177^{\mathrm{ab}} \pm 4.15$ & $17.1186^{\mathrm{a}} \pm 0.34$ & $1.67 \pm 0.21$ \\
$\mathrm{CE}$ & $74.1738^{\mathrm{b}} \pm 13.53$ & $185.1948^{\mathrm{c}} \pm 16.93$ & $1.39 \pm 0.14$ \\
$\mathrm{EA}$ & $224.3173^{\mathrm{d}} \pm 16.69$ & $20.2999^{\mathrm{a}} \pm 5.23$ & $0.20 \pm 0.25$ \\
$\mathrm{EE}$ & $106.6803^{\mathrm{c}} \pm 12.51$ & $48.3302^{\mathrm{b}} \pm 1.50$ & $0.63 \pm 0.24$ \\
$\mathrm{MA}$ & $117.7052^{\mathrm{c}} \pm 10.94$ & $12.9476^{\mathrm{a}} \pm 2.96$ & $1.12 \pm 0.26$ \\
ME & $47.1230^{\mathrm{a}} \pm 3.69$ & $190.9917^{\mathrm{c}} \pm 14.58$ & $3.08 \pm 1.53$ \\
Probability & 0.000 & 0.000 & - \\
Signification & HS & HS & - \\
\hline
\end{tabular}

Note. CA: Cympopogon citratus aqueous, CE: C. citratus ethanolic, EA: Eucalyptus camaldulensis aqueous, EE: Eucalyptus camaldulensis ethanolic; MA: Mentha piperita aqueous; ME: Mentha piperita ethanolic. HS: Highly Significant 
Aqueous extract of eucalyptus (EA) has the highest total polyphenol levels assessed at $224.31 \mathrm{mg} \mathrm{GAE} / \mathrm{g}$ of dry extract. The lowest content is showed by the mentha ethanolic extract ME with $47.12 \pm 3.69 \mathrm{mg} \mathrm{GAE} / \mathrm{g}$ of dry extract. The qualitative analysis of flavonoids by TLC was done the six different extracts (Figure 3).

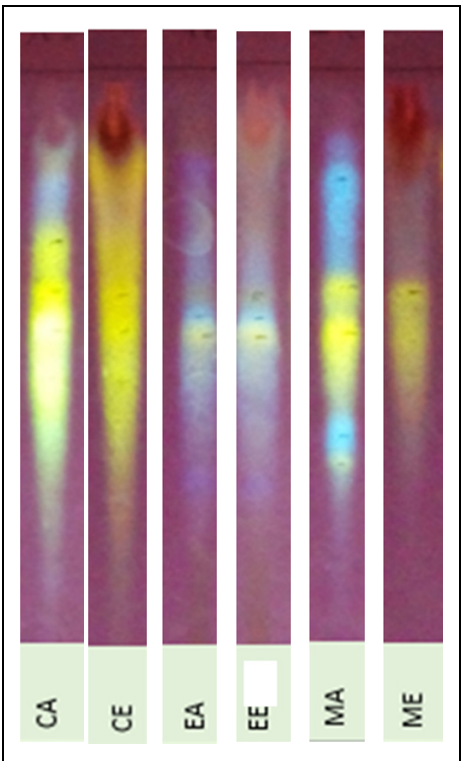

Figure 3. TLC plates of extracts from the three plant after Neu reagent pulverization (Observation under $\lambda=365 \mathrm{~nm}$ )

Note. CA: Cympopogon citratus aqueous, CE: C. citratus ethanolic, EA: Eucalyptus camaldulensis aqueous, EE: Eucalyptus camaldulensis ethanolic; MA: Mentha piperita aqueous; ME: Mentha piperita ethanolic.

After the revelation with the Neu reagent on the TLC plates, yellow spots which are characterizing flavonoids are presents for some extracts.

\subsection{Antioxidant Activity}

In general, aqueous extracts of mentha and lemongrass have lowest $\mathrm{IC}_{50}$ than their ethanolic extracts. However, the aqueous extract of eucalyptus presents the lowest value of antioxidant activity as $\mathrm{IC}_{50}, 0.20 \mathrm{mg} / \mathrm{ml}$ compared to Trolox which $\mathrm{IC}_{50}, 0.15 \mathrm{mg} / \mathrm{ml}$.

\subsection{Effect Towards Termites}

The non-choice screening test was valid as the survival rate of the controls (water and ethanol) is above $50 \%$, and the paper (being changed twice during the 18 day test) has been totally degraded (Bedoungindzi et al., 2020).

The effect of C. citratus, E. camaldulensis and M. piperita extracts on termites are evaluated (Table 3). The anti-termitic efficacy of one extract conducts to the mortality of termites when the treated paper is degraded by termites. With applied concentrations of $2.5,5$, and $10 \%(\mathrm{w} / \mathrm{w})$ of extract, some extracts present anti-termite activity. 
Table 3. Results of termite non-choice screening tests

\begin{tabular}{|c|c|c|c|c|c|c|c|c|c|}
\hline \multirow{2}{*}{$\begin{array}{l}\text { Concentration of } \\
\text { extract } \%(w / w)\end{array}$} & \multicolumn{3}{|c|}{2.5} & \multicolumn{3}{|c|}{5} & \multicolumn{3}{|c|}{10} \\
\hline & $\begin{array}{l}\text { Exposure } \\
\text { Duration } \\
\text { (days) }\end{array}$ & $\begin{array}{l}\text { Survival } \\
\text { Rate } \\
(\%)\end{array}$ & $\mathrm{SD}(\%)$ & $\begin{array}{l}\text { Exposure } \\
\text { Duration } \\
\text { (days) }\end{array}$ & $\begin{array}{l}\text { Survival } \\
\text { Rate } \\
(\%)\end{array}$ & $\mathrm{SD}(\%)$ & $\begin{array}{l}\text { Exposure } \\
\text { Duration } \\
\text { (days) }\end{array}$ & $\begin{array}{l}\text { Survival } \\
\text { Rate } \\
(\%)\end{array}$ & $\mathrm{SD}(\%)$ \\
\hline $\mathrm{CA}$ & 7 & 76 & 100 & 7 & 66 & 100 & 7 & 80 & 100 \\
\hline $\mathrm{CE}$ & 7 & 85 & 100 & 11 & 91 & 100 & 7 & 83 & 100 \\
\hline EA & 7 & 75 & 100 & 7 & 96 & 100 & 7 & 83 & 100 \\
\hline $\mathrm{EE}$ & 7 & 58 & 100 & 24 & 0 & 20 & 24 & 0 & 10 \\
\hline MA & 10 & 95 & 100 & 6 & 83 & 100 & 21 & 75 & 100 \\
\hline ME & 10 & 82 & 100 & 10 & 87 & 100 & 12 & 67 & 100 \\
\hline W. CL & 18 & 90 & 100 & 18 & 90 & 100 & 18 & 90 & 100 \\
\hline E. CL & 18 & 85 & 100 & 18 & 85 & 100 & 18 & 85 & 100 \\
\hline
\end{tabular}

Note. CA: Cympopogon citratus aqueous, CE: C. citratus ethanolic, EA: Eucalyptus camaldulensis aqueous, EE: Eucalyptus camaldulensis ethanolic; MA: Mentha piperita aqueous; ME: Mentha piperita ethanolic, W. CL: water control, E. CL: ethanol control; SD: Surface Degradation (of paper loaded with extract or solvent).

\section{Discussion}

Farmers from Burkina Faso commonly use the aqueous extracts of plants as biopesticides (Pretty, 2005), but a significant part of polar constituents remains in the solid residue rejected after filtration. The aqueous extract after hydrodistillation of aromatic plants constitutes a decoction containing hydrosoluble substances. From three studied aromatic plants, six extracts were obtained as aqueous and ethanolic extracts of the residue after hydrodistillation for each sample: C. citratus, E. camaldulensis and M. piperita. Aqueous extraction process of powders gave higher quantity of product compared to ethanolic extraction. The ethanolic extract of $E$. camaldulensis gave the higher percentage with $13.64 \%$ of extraction yield which is about three times higher than the other yields. In addition, high total extraction yield was obtained with E. camaldulensis with $42.24 \%$ followed by $M$. piperita. Before collecting any information on the nature of the chemical constituents in different extracts, the calcination gave a previous view on organic and inorganic parts. The six extracts were submitted to calcination to evaluate the residual ash which could be assimilated to minerals contents. Minerals compounds are present in biomass after absorption by the plant from roots for plant vital growth and development. Some minerals represent nutritional value for plants: ( $\mathrm{Ca}, \mathrm{Cu}, \mathrm{Fe}, \mathrm{K}, \mathrm{Mg}, \mathrm{Mn}, \mathrm{Na}, \mathrm{P}, \mathrm{S}$ and $\mathrm{Zn}$ ) and some heavy metals in minors levels (Cd, $\mathrm{Co}, \mathrm{Cr}$ and $\mathrm{Pb}$ ) are pollutants. When the dried biomass is calcinated through combustion, the ash is composed by these mixtures of minerals as oxides. It is known also that some minerals can interfere in chemical reactions during the organic compound's extraction. Therefore, before polyphenolic and flavonoid quantification, the percentage of mineral must be evaluated. There was no ash for ethanolic extract from the three plants. The different evolution in ash contents observed between plants during water extraction depends on the types of minerals and the biomass. For example Mentha piperita, well known aromatic plant, has a nutritious value and the minerals determined in the ash were K: $1.16 \% \mathrm{w} / \mathrm{w}, \mathrm{Ca}: 1.25 \% \mathrm{w} / \mathrm{w}$ and $\mathrm{Mg}: 0.210 \% \mathrm{w} / \mathrm{w}$ (Esetlili et al., 2014). Eucalyptus camaldulensis leave powder has a low content in minerals and water extraction generated more extractives as organic compounds than minerals. One can note that aqueous extract has the advantage to collect high mineral quantities in addition to organic substances. Minerals are more soluble in water that is why percentage of ash in aqueous extracts presents higher values that the ash from the air dried powder. When the crude powder present less, ash percentage as for eucalyptus, the percentage of ash from the aqueous extract is also the less.

All polyphenolics are not totally extracted by water during hydrodistillation, so they can partly remain in the solid residues (Espana et al., 2017, Abu-Jafar \& Huleihel, 2017). The ethanol additional extraction of these solid residues proved to be very effective as it made possible to exhaust from the solid residue further important quantities of organic compounds. Polyphenols with high molecular weight are considered with less solubility in water but according to Navarrete et al. (2011) ethanolic extract of solid residues from hydrodistillation are particularly rich in polyphenols.

The total polyphenol content in the aqueous eucalyptus extract which presents the highest value $(224.31 \mathrm{mg}$ GAE/g of dry extract) found in this study is different from the one reported by Singab et al. (2011), who found that the total polyphenol content of the water extract was the lowest $(110.10 \pm 18.10 \mathrm{mg}$ GAE/g) compared to their methanolic extracts $(653.5 \pm 21.50 \mathrm{mg} \mathrm{GAE} / \mathrm{g}$ and MeOH 60\% v/v (701.10 $\pm 16.70 \mathrm{mg}$ GAE/g). Concerning flavonoid content of extracts, ethanolic extracts seems to have highest flavonoid contents compared to the aqueous 
extracts of the three plants particularly for lemongrass and mentha. Alcohol like ethanol, and water are the most commonly used solvents to extract flavonoids because they form strong hydrogen-bonding interactions with the hydroxyl, carbonyl groups of flavonoids as shown for rutin (Gullon et al., 2017). Indeed, the highest-content in flavonoids for the mentha ethanol extract $(190.99 \pm 14.58 \mathrm{mg}$ QE/g of dry extract) is followed by the lemongrass ethanol extract: CE (185.19 mg QE/g of dry extract). The mentha aqueous extract showed the lowest content (12.94 mg QE/g of dry extract) in flavonoids followed by the aqueous extract of C. citratus: CA (17.11-0.34 mg QE/g of dry extract). These results are consistent with the study conducted by Singab et al. (2011), where the total flavonoid content is the lowest in the aqueous extract (53.00-0.60 mg QE/g of dry extract) compared to the methanol extract. It is depicted that alcohol, like methanol, is a successful solvent for extraction of flavonoid contents from plants. Glycoside flavonoids found mostly in plants and polyhydroxide aglycones are extracted with alcohol or hydroalcoholic mixtures (Andersen \& Markham, 2005; Gullon et al., 2017). The extraction process can also explain the co-extraction of minerals with organics by water as showed for fulvic and humic acids (Harper et al., 2000). The yellow color of spots on TLC plate is an indication for flavonols and the fluorescent one is an indication for flavones.

One can note for the three plants, the more the ethanolic extract presents high content in flavonoids, the more powder contents minerals represented by ash percentage. This is in accordance with Kasprzak et al. (2015) view as flavonoid accumulation was attributed to a protection mechanism against metal ion toxicity in plants. This hypothesis is verified with three plants in our case. Mentha piperita presented the highest-content in flavonoids for the mentha ethanol extract $(190.99 \pm 14.58 \mathrm{mg} \mathrm{QE} / \mathrm{g}$ of dry extract) and the higher percentage in ash (14\% $\mathrm{w} / \mathrm{w}$ ) for the dry powder followed by the lemongrass. Eucalyptus ethanolic extract showed the lowest content in flavonoids $(48.33 \pm 1.5 \mathrm{mg} \mathrm{QE} / \mathrm{g}$ of dry extract in correlation with the lowest percentage of ash $(8 \% \mathrm{w} / \mathrm{w})$ for the dry powder.

The data on antioxidant potential of extract is more in line with the polyphenolic contents than with the flavonoid contents. Consequently, mentha ethanolic extract, the richest extract in flavonoids presented the lowest antioxidant activity.

Analysis of data of surface degradation (SD) and termite survival rate showed that the extracts at a concentration of $2.5 \%$ were found ineffective. At $5 \%$ concentration, the extracts exhibited also no significant termiticidal activity, except for eucalyptus ethanolic extract (EE). At $5 \%$ and $10 \%$, EE treated paper was degraded up to $20 \%$ and $10 \%$ respectively, and the termite mortality was total after the paper ingestion, showing a toxic activity towards termites. No repellent or toxic activity was noted with the eucalyptus aqueous extract. This anti-termite potentiality in a first view seems to not be due to total phenolic content as E. camaldulensis aqueous extract EA with higher antioxidant activity $\left(\mathrm{IC}_{50}=0.20 \mathrm{mg} / \mathrm{ml}\right)$ and polyphenol content $(224.32 \mathrm{mg} \mathrm{GAE} / \mathrm{g}$ of dried extract). From literature data, flavonoids identified in E. camadulensis leaves are quercetin, a flavonol confirmed by the yellow color on TLC plate and 3-O-monoglycosides kaempferol (Ashraf et al., 2015). Between polyphenolics found in E. camaldulensis leaves, many acids are identified: gallic, betulinic, ursolic, vanillic and syringic acids (Ashraf et al., 2015). In the same analysis, $M$. piperita and C. citratus ethanolic extracts with higher flavonoid contents (190.99 and $185.19 \mathrm{mg}$ QE/g of dried extract) presented no effect on termites. The particularity of ethanolic extract of eucalyptus compared to the two others could be that it contents no minerals and there is the highest content in polyphenols $106.68 \pm 12.51 \mathrm{mg}$ QE.GA/g of dried extract and the interesting antioxidant activity $\left(\mathrm{IC}_{50}\right.$ $=0.63 \pm 0.24 \mathrm{mg} / \mathrm{ml}$ ). The main functional components including phenolic acids and flavonoids are known for antibacterial properties.

Phenolic acids and flavonoids have been shown to be active against termites, but the extent of their antifeedant and toxic properties depend on their structure (Boué \& Raina, 2003; Ohmura et al., 2000) and this could therefore explain the observed termiticidal properties of E. camaldulensis leaves. Flavonoids in mentha are more glycosides which are found less bioactive as antifungal compounds than aglycones (Ilboudo et al., 2012). As the ethanolic extract of E. camaldulensis gave the highest extraction yield (13.64\%) which is about three times higher than other values, it can be a source of interesting active ingredients for anti-termite formulations. Litterature review showed some data on various extracts screened for termicidal activity potential (Krupal et al., 2017; Pardede et al., 2018; Azab, 2018). Data on four selected plants tested for anti-termiticidal activities showed that methanol extracts of the stem of Terminalia arjuna (Myrtales: Combretaceae) exhibited the highest potential for termite mortality. This extract registered higher amounts of flavonoid and tanin contents (Krupal et al., 2017) than others extracts rich on alkaloids, saponins, phenols, carbohydrates and proteins. On the opposite, a n-hexane extract of Prosopis farcta (Fabales: Fabaceae) with low polyphenol content presented the highest antifungal and anti-termite activities when methanolic and aqueous extracts with high contents in phenolics present least activity (Azab, 2018). Five compounds were isolated from Coreopsis lanceolata (Asterales: 
Asteraceae) stems and identified. Their antitermitic effects against Coptotermes curvignathus (Blattodea: Rhinotermitidae) were evaluated. 5-phenyl-2-(1-propynyl)-thiophene (1) and 1-phenylhepta-1, 3,5-tryne (2) showed strong potent antitermitic activity in comparation with other compounds: $\beta$-sitosterol (3), succinic acid (4), and protocatechuic acid (5) (Pardede et al., 2018). Between four plants tested Maranta arundinaceae (Zingiberales: Marantaceae) and Acorus calamus (Acorales: Acoraceae) were found to possess maximum phytochemicals compared to Alpinia galanga (Zingiberales: Zingiberaceae) and Hedysarum coronarium (Fabales: Fabaceae). These last ones were tested positive for termicidal activity against two species of termites, Coptotermes gestroi (Blattodea: Rhinotermitidae) and Coptermes curvignathus (Blattodea: Rhinotermitidae) but presented few major phytochemicals as proteins, carbohydrates, oils, saponins, terpenoids, alkaloids, steroids, flavonoids and cardiac glycosides. The authors noted that phenylpropanoids and p-hydroxybenzaldehyde were identified in the rhizome of $A$. galanga (Sowmya, 2016). We noted that the organic phytochemicals responsible for the termite activity are various and need to be still clarified.

Futher studies to elucidate the contribution of the minerals on anti-termite activities for mentha and cympopogon species are currently underway, as the tendency of polyphenolic compounds to chelate metals by complexation is crucial in anti-oxidant activity and biological activities. (Kasprzak et al., 2015; Meera et al., 2019; Khater et al., 2019), R. flavipes as rhinotermitidae termite gain nutrients from food sources and some for soils as $\mathrm{Ca}, \mathrm{Fe}, \mathrm{Mg}$ and $\mathrm{Mn}$ were uptaked from the soil (Janzow et al., 2015). They can regulate their diets based on the availability of several inorganic nutrients by adjusting their intake from multiple resources (Poisonnier et al., 2020). In the experimentation, the food consumption based on cellulosic paper charged with extracts suggests that termites also have internal systems to detect the levels of several inorganic in aqueous extracts and it is possible that these insects prefer foods with higher levels of minerals to meet their own nutritional demands (Judd et al., 2017).

\section{Conclusion}

Polyphenols as phenolic acids or flavonoids are present in the three different aromatic plants used is this study. Valorization of the hydrodistillation residues as extractives in aqueous phase and ethanolic extract of solids residues showed relative anti-termite activity. Ethanolic extract of E. camaldulensis presenting no minerals, lower contents in polyphenolic compounds compared to aqueous extract had the highest anti-termite activity, for the concentrations used. This content in polyphenolics is the highest compared to ethanolic extracts of $M$. piperita and $C$. citratus. Our data pay the way for development of bioproducts for potential application in plant protection against termites. This valorization constitutes an added-value for aromatic plants from Burkina Faso, which are abundant, cultivable and produce interesting, high value co-products to essential oils production.

\section{Acknowledgements}

The authors are thankful to international Science Programme (ISP) for providing financial support to the BUF 01 project to carry out the present work. They are also grateful to the CIRAD, for Assétou Sankara fellowship for her training at CIRAD Montpellier.

\section{References}

Abu-Jafar, A., \& Huleihel M. (2017). Antiviral activity of Eucalyptus camaldulensis leaves ethanolic extract on herpes viruses infection. International Journal of Virology, 1, 001-009, https://doi.org/10.29328/journal.ijcv. 1001001

Adeniyi, B. A., \& Ayepola, O. O. (2008). The phytochemical screening and antimicrobial activity of leaf extracts of Eucalyptus camaldulensis and Eucalyptus torelliana (Myrtaceae). Research Journal of Medicinal Plants, 2, 34-38. https://doi.org/10.3923/rjmp.2008.34.38

Andersen, O. M., \& Markham, K. R. (2005). Flavonoids: Chemistry, Biochemistry and Applications (1st ed., p. 1256). CRC Press, Boca Raton, FL.

Ashraf, A., Sarfraz, R. A. Mahmood, A., \& Din, M. (2015). Chemical composition and in vitro antioxidant and antitumor activities of Eucalyptus camaldulensis Dehn. leaves. Industrial Crops and Products, 74, 241-248. https://doi.org/10.1016/j.indcrop.2015.04.059

Azab, A. (2018). Antifungal and anti-termite activities, total phenolic content of Prosopis farcta extracts; attempts to develop weed biocontrol method against it. European Chemical Bulletin, 7(10), 293-302, https://doi.org/10.17628/ecb.2018.7.293-302

Bédounguindzi, W. F., Candelier, K., Engonga, E. P., Dumarçay, S., Thévenon, M. F., \& Gérardin, P. (2020). Anti-termite and anti-fungal bio-sourced wood preservation ingredients from Dacryodes edulis (G. Don) H.J. Lam resin. Holzforschung (p. 9). https://doi.org/10.1515/hf-2019-0106 
Boué, S. M., \& Raina, A. K. (2003). Effects of plant flavonoids on fecundity, survival, and feeding of the formosan subterranean termite. Journal of Chemical Ecology, 29(11), 2575-2584. https://oi.org/10.1023/ a: 1026318203775

Esetlili, B. C., Pekcan, T., Çobanoglu, O., Aydoğdu, E., Turan, S., \& Anaç D. (2014). Essential Plant Nutrients and Heavy Metals Concentrations of Some Medicinal and Aromatic Plants. Journal of Agricultural Sciences, 20, 239-247, https://doi.org/10.1501/Tarimbil_0000001283

España, M. D., Arboleda, J. W., Ribeiro, J. A., Abdelnur, P. V., \& Guzman, J. D. (2017). Eucalyptus leaf byproduct inhibits the anthracnose-causing fungus Colletotrichum gloeosporioides. Industrial Crops and Products, 108, 793-797. https://doi.org/10.1016/j.indcrop.2017.08.002

García Serna, J., Pérez-Barrigón, L., \& Cocero, M. (2007). New trends for design towards sustainability in chemical engineering: Green engineering. Chemical Engineering Journal, 7-30. https://oi.org/10.1016/ j.cej.2007.02.028

Ghareeb, M. A., Habib, M. R., Mossalem, H. S., \& Abdel-Aziz M. S. (2018). Phytochemical analysis of Eucalyptus camaldulensis leaves extracts and testing its antimicrobial and schistosomicidal activities. Bulletin of the National Research Centre, 42, 16. https://doi.org/10.1186/s42269-018-0017-2

Ghasemian, A., Eslami, M., Hasanvand, F., Bozorgi, H., \& Al-Abodi, H. (2019). Eucalyptus camaldulensis properties for use in the eradication of infections. Comparative Immunology Microbiology and Infectious Diseases, 65, 234-237. https://doi.org/10.1016/j.cimid.2019.04.007

Gullon, B., Lu-Chau, T. A., Moreira, M. T., Lema, J. M., \& Eibes, G. (2017). Rutin: A review on extraction, identification and purification methods, biological activities and approaches to enhance its bioavailability. Trends Food Sciences and Technology, 67, 220-235. https://doi.org/10.1016/j.tifs.2017.07.008

Hannon, J., \& Zaman, A. (2018). Exploring the Phenomenon of Zero Waste and Future Cities. Urban Science, 2 , 90. https://doi.org/10.3390/urbansci2030090

Harper, S. M., Kerven, G. L., Edwards, D. G., \& Ostatek-Boczynski, Z. (2000). Characterisation of fulvic and humic acids from leaves of Eucalyptus camaldulensis and from decomposed hay. Soil Biology \& Biochemistry, 320, 1331-1336. https://doi.org/10.1016/S0038-0717(00)00021-3

Ibrahim, B. U., \& Adebote, D. A. (2012). Appraisal of the economic activities of termites: A review. Bayero Journal of Pure and Applied Sciences, 5(1), 84-89. https://doi.org/10.4314/bajopas.v5i1.16

Ilboudo, O., Bonzi, S., Tapsoba, I., Somda, I., \& Bonzi-Coulibaly, Y. L. (2016). In vitro antifungal activity of flavonoid diglycosides of Mentha piperita and their oxime derivatives against two cereals fungi. Comptes Rendus Chimie, 19(7), 857-862. https://doi.org/10.1016/j.crci.2015.11.023

Ilboudo, O., Ouédraogo, I. W., Tapsoba, I., Gerbaux, P., \& Bonzi-Coulibaly L. Y. (2012). Analysis of flavonoid diglycosides in leaves of Mentha piperita L by MALDI-MS/MS and LC-MS. Natural Products. An Indian Journal, 8, 321-327.

Irshad, M., Subhani, M. A., Ali, S., \& Hussain, A. (2019). Biological importance of essential oils. Intechopen Editions. https://doi.org/10.5772/intechopen.87198

Janzow, M. P., \& Judd, T. M. (2015). The Termite Reticulitermes flavipes (Rhinotermitidae: Isoptera) Can Acquire Micronutrients from Soil, Environmental Entomology, 44(3), 814-820, https://doi.org/10.1093/ee/ nvv041

Jouquet, P., Traoré, S., Choosai, C., Hartman, C., \& Bignell, D. (2011). Influence of termites on ecosystem functioning. Ecosystem serice provided by termites. European Journal of Soil Biology, 47(4), $215-222$. https://doi.org/10.1016/j.ejsobi.2011.05.005

Judd, T., Landes, J., Ohara, H., \& Riley, A. (2017). A geometric analysis of the regulation of inorganic nutrient intake by the subterranean termite Reticulitermes flavipes Kollar. Insects, 8, 97. https://doi.org/10.3390/ insects 8030097

Kaiser, D., Tra-Bi, C. S., Yeo, K., Konate, S., \& Linsenmair, K. E. (2015). Species richness of termites (Blattoidea: Termitoidae) and ants (Hymenoptera: Formicidae) along disturbance gradients in semi-arid Burfina Faso (West Africa). Bonn Zoological Bulletin, 64(1), 16-31.

Kasprzak, M. M., Erxleben, A., \& Ochocki, J. (2015). Properties and Applications of Flavonoid Metal Complexes. RSC Advances, 5, 45853-45877. https://doi.org/10.1039/C5RA05069C 
Khater, M., Ravishankar, D., Greco, F., \& Osborn, H. (2019). Metal complexes of flavonoids: Their synthesis, characterization and enhanced antioxidant and anticancer activities. Future Medicinal Chemistry, 11(21), 2845-2867. https://doi.org 10.4155/fmc-2019-0237

Korb, J., Kasseney, B. D., Cakpo, Y. T., Casalla Daza, R. H., Gbenyedji, J. N. K. B., Ilboudo, M. E., ... Sankara, F. (2019). Termite taxonomy, challenges and prospects: West Africa, a case example. Insects, $10(32), 8$. https://doi.org/10.3390/insects10010032

Krupal, K. P., \& Narasimhacharya, A. V. R. L. (2017). Anti-termite activity of certain plants against Odontotermes obesus. Journal of Biopesticides, 10(2), 120-129

Lawal, O. A., Ogunddajo, A. L., Avoseh, N. O., \& Ogunwande, I. A. (2017). Chapter 18: Cymbopogon citratus. Medicinal spices and vegetables from Africa (pp. 397-423). Elsevier. https://doi.org/10.1016/B978-012-809286-6.00018-2

Mahendra, G., \& Rahman, L. U. (2020). Ethnomedicinal, phytochemical and pharmalogical updates on peppermint (Mentha $\times$ piperita L.) - A review. Phytotherapy Research (pp. 1-52). Wiley Online Library. https://doi.org/10.1002/ptr.6664

Meera, I., \& Sivakumar, Ch. V. (2019). Screening of medicinal plants for iron chelating and antioxidant activity. Biotechnology Society, 12(2), 30-36. Retrieved from http://hdl.handle.net/123456789/2529

Miean, K. H., \& Mohamed, S. (2001). Flavonoid (myricetin, quercetin, kaempferol, luteolin, and apigenin) content of edible tropical plants. Journal of Agricultural Food Chemistry, 49, 3106-3112, https://doi.org/ $10.1021 / \mathrm{jf000892m}$

Miliauskas, G., Venskutonis, R. P., \& van Beek, T. A. (2004). Screening of radical scavenging activity of some medicinal and aromatic plant extracts. Food Chemistry, 85(2), 231-237, https://doi.org/10.1016/j.foodchem. 2003.05.007

Mirabella, N., Castellani, V., \& Sala, S., (2014). Current options for the valorization of food manufacturing waste: A review. Journal of Cleaner Production, 65, 28-41. https://doi.org/ 10.1016/j.jclepro.2013.10.051

Morin, N. C., Horn, R. C., Oliveira, C., Tassotti Gelatti, G., Klafke, J. Z., Tissiani, A. C., ... Tomazetti Micheloti, B. (2017). Effect of the Cymbopogon citratus Infusion on the Activity of Acetylcholinesterase Enzyme and on the Redox Profile in Farmers' Erythrocytes. Journal of Agricultural Science, 9(9), https://doi.org/ 10.5539/jas.v9n9p68

Moure, A., Cruz, J. M., Franco, D., Domínguez, J. M., Sineiro, J., Domínguez, H., ... Parajó, J. C. (2001). Natural antioxidants from residual sources. Food Chemistry, 72, 145-171. https://doi.org/10.1016/ S0308-8146(00)00223-5

Navarrete, A., Herrero, M., Martín, Á., Cocero, M., \& Ibáñez, E. (2011). Valorization of solid wastes from essential oil industry. Journal of Food Engineering, 104, 196-201. https://doi.org/10.1016/j.jfoodeng. 2010.10.033

Negrelle, R. R., \& Gomes, E. C. (2007). Cymbopogon citratus (DC) Stapf: chemical composition and biological activities. Revista Brasileira de Plantas Medicinais, Botucatu, 9(1), 80-97.

Ohmura, W., Dois, S., Aoyama, M., \& Ohara, S. (2000). Antifeedant activity of flavonoids and related compounds against the subterranean termite Coptotermes formosanus Shiraki. Journal of Wood Science, 46, 149-153. https://doi.org/10.1007/BF00777362

Olufunmilayo, E. A., Ajayi, A. A., Adedire, C. O., \& Lajide, L. (2012). Evaluation of Partially Purified Fractions of Crude Extracts of the Leaves of Morinda lucida (Benth.) and Datura stramonium (L.) for Suppression of Wood Damage by Subterranean Termites. Journal of Agricultural Science, 4(5), 125-130. https://doi.org/ $10.5539 /$ jas.v4n5p125

Pardede, A., Adfa, M., Kusnanda, A. J., Ninomiya, M., \& Koketsu, M. (2018). Chemical Constituents of Coreopsis lanceolata Stems and Their Antitermitic Activity Against the Subterranean Termite Coptotermes curvignathus. Journal of Economic Entomology, 111(2), 803-807. https://doi.org/10.1093/jee/tox376

Poissonnier, L. A., Simpson, S. J., Dussutour, A., \& Buhla, J. (2020). Regulation of macronutrient intake in termites: A dietary self-selection experiment. Journal of Insect Physiology, 120, 103983. https://doi.org/ 10.1016/j.jinsphys.2019.103983

Pretty, J. (2005). The pesticide detox: Towards a more sustainable agriculture (p. 293). Earthscan Edition. 
Sankarikutty, B., \& Narayanan, C. S. (2003). Essential oils: Isolation and production. Encyclopedia of food sciences and nutrition (2nd ed., pp. 2185-2189). https://doi.org/10.1016/B0-12-227055-X/00426-0

Santana-Méridas, O., González-Coloma, A., \& Sánchez-Vioque, R. (2012). Agricultural residues as a source of bioactive natural products. Phytochemical Review, 11, 447-466. https://doi.org/10.1007/s11101-012-9266-0

Santana-Méridas, O., Polissiou, M., Izquierdo-Melero, M. E., Astraka, K., Petros A. T., Herraiz-Penalver, D., \& Sánchez-Vioque, R. (2014). Polyphenol composition, antioxidant and bioplaguicide activities of the solid residue from hydrodistillation of Rosmarinus officinalis L.O. Industrial Crops and Products, 59, 125-134. https://doi.org/10.1016/j.indcrop.2014.05.008

Schyra, J., \& Korb, J. (2019). Termite communities along a disturbance gradient in a West African Savanna. Insects, 10(17), 12. https://doi.org/10.3390/insects 10010017

Shafique, S., \& Ahmed, A. (2017). Defense response of Eucalyptus camaldulensis against black spot pathogen of Pisum sativum. South African Journal of Botany, 113, 428-436, https://doi.org/10.1016/j.sajb.2017. 09.021

Siddiqui, S. B., Sultana, I., \& Begum, S. (2000). Triterpenoidal constituents from Eucalyptus camaldulensis var. obtusa leaves. Phytochemistry, 54, 861-865. https://doi.org/10.1016/S0031-9422(00)00058-3

Singab, A. N., Ayoub, N., Al Sayed, E., Martiskainen, O., Sinkkonen, J., \& Pihlaja, K. (2011). Phenolic constituents of Eucalyptus camaldulensis Dehnh, with potential antioxidant and cytotoxic activities. Records of Natural Products, 5, 271-280.

Singleton, V. L., Orthofer, R., \& Lamuela-Raventos, R. M. (1999). Analysis of total phenols and other oxidation substrates and antioxidants by means of Folin-Ciocalteu Reagent. Methods in Enzymology, 299, 152-178. https://doi.org/10.1016/S0076-6879(99)99017-1

Sowmya, S. (2016). Anti-termite properties of four selected species of Zingiberaceae rhizome extracts. The Journal of Zoology Studies, 3(2), 23-28.

Texeira, B., Marques, A., Ramos, C., Neng, N. R., Nogueira, J. M. F., Saraiva, J. A., \& Nunes, M. L. (2013). Chemical composition and antibacterial and antioxidant properties of commercial essential oils. Industrial Crops and Products, 43, 587-595. https://doi.org/10.1016/j.indcrop.2012.07.069

Torras-Claveria, L., Jáuregui, O., Bastida, J., Codina, C., \& Viladomat, F., (2007). Antioxidant activity and phenolic composition of lavandin (Lavandula $\times$ intermedia Emeric ex Loiseleur) waste. Journal of Agricultural Food Chemistry, 55, 8436-8443. https://doi.org/10.1021/jf070236n

Woisky, R. G., \& Salatino A. (1998). Analysis of Propolis: Some Parameters and Procedures for Chemical Quality Control. Journal of Apicultural Research, 37(2), 99-105. https://doi.org/10.1080/00218839.1998. 11100961

Zerbo, P., Millogo-rasolodimby, J., Nacoulma-Ouédraogo, O. G., \& Van Damme, P. (2011). Medicinal plants and medical practice in Burkina Faso: A case study on the San people. Bois et Forêt des Tropiques, 307(1), 41-53. https://doi.org/10.19182/bft2011.307.a20481

\section{Copyrights}

Copyright for this article is retained by the author(s), with first publication rights granted to the journal.

This is an open-access article distributed under the terms and conditions of the Creative Commons Attribution license (http://creativecommons.org/licenses/by/4.0/). 